\title{
DERMIS-FAT GRAFT FOR CORRECTION OF RECURRENT SEVERE UPPER EYELID RETRACTION IN GRAVES' ORBITOPATHY
}

\author{
Biljana Kuzmanović Elabjer, Daliborka Miletić, Mladen Bušić, \\ Ana Bišćan Tvrdi, Damir Bosnar and Mirjana Bjeloš
}

University Eye Department, Faculty of Dental Medicine and Health Care Osijek, Faculty of Medicine Osijek, Josip Juraj Strossmayer University in Osijek, Sveti Duh University Hospital, Zagreb, Croatia

SUMMARY - Dermis-fat graft has been proven as a useful replacement tissue for eyelid and orbit reconstruction, but there is no evidence in the literature that it can be used for correction of upper eyelid retraction. This is the first report that presents two cases (four eyelids) of dermis-fat graft usage as a spacer in the treatment of severe recurrent upper eyelid retraction due to Graves' orbitopathy. Improvement was achieved with minimum complications, patient symptoms were reduced, and the results were stable almost three years after the procedure.

Key words: Graves ophthalmopathy - surgery; Eyelids - surgery; Reconstructive surgical procedures methods; Skin transplantation; Autografts; Dermis-fat graft

\section{Introduction}

Graves' orbitopathy is an autoimmune condition mostly related to hyperthyroidism in Graves' disease. It carries a great risk of ocular morbidity, one of which is upper eyelid retraction present in more than $90 \%$ of patients ${ }^{1}$. In its pathogenesis, the key role is played by inflammation and consequent fibrosis of two major upper eyelid retractors, levator palpebrae and Müller's muscle. Additional factors are tightening of the rectus inferior muscle, causing an overshoot of upward gaze of the affected eyelid, and proptosis ${ }^{1}$. Rigid muscles cannot fully contract or relax, thus resulting in retracted eyelid and lid lag, exposure keratopathy and subsequent loss of vision. When proptosis is the dominant sign, it should be addressed first. Residual retraction is treated with blepharotomy, upper eyelid retractor recession and grafting ${ }^{2-4}$. In marked upper eyelid retrac-

Correspondence to: Prof. Mladen Bušić, MD, PhD, University Eye Department, Faculty of Medicine, Josip Juraj Strossmayer University in Osijek, Sveti Duh University Hospital, Sveti Duh 64, HR10000 Zagreb, Croatia

E-mail: mbusic@kbsd.hr

Received October 26, 2016, accepted December 4, 2017 tion of $4 \mathrm{~mm}$ or more, a spacer may be indicated, many of which have been described ${ }^{5-8}$. Dermis-fat graft has been proven to be a useful replacement tissue for eyelid and orbit reconstruction ${ }^{9,10}$. It is a suitable lower eyelid posterior lamella spacer graft for repair of lower eyelid malposition ${ }^{11}$. The authors found no proof in the available literature of its usage as a spacer in upper eyelid retraction surgery.

\section{Case Report}

A 63-year-old (Case 1, Fig. 1A) and 46-year-old (Case 2, Fig. 2A) Caucasian females with Graves'orbitopathy were referred for correction of bilateral severe recurrent upper eyelid retraction in July 2013. Orbital decompression proposed to the patients was declined. Previous attempts at retractor lengthening via blepharotomy followed by anterior approach Z-myotomy were unsuccessful leading to early postoperative recurrence. Both patients had pronounced symptoms of dry eye despite intensive lubrication. Upon examination proptosis, upper and lower eyelid retraction with massive scleral show, lagophthalmus, conjunctival hyper- 


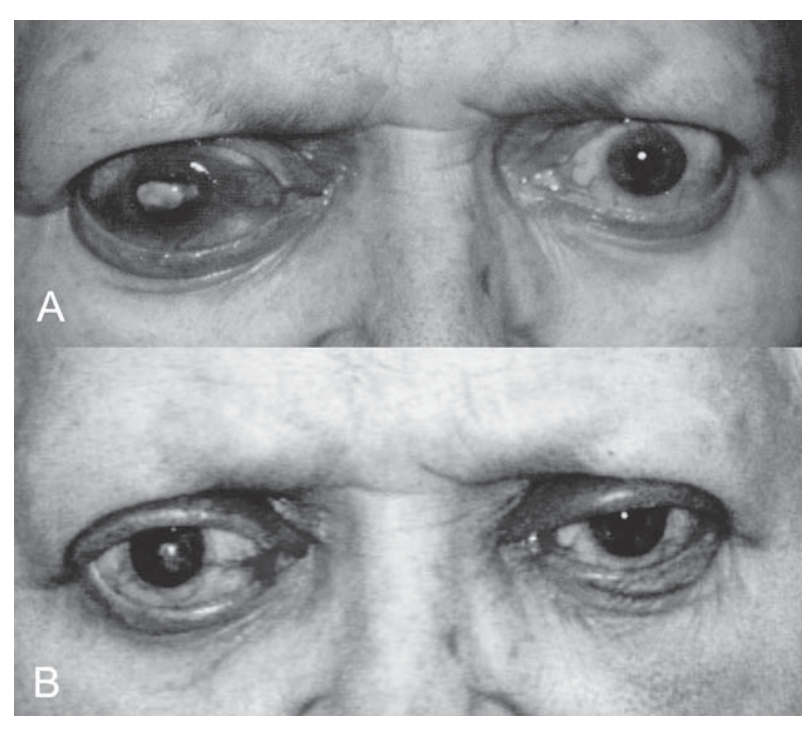

Fig. 1. Case 1 preoperatively $(A)$ and one month postoperatively (B).

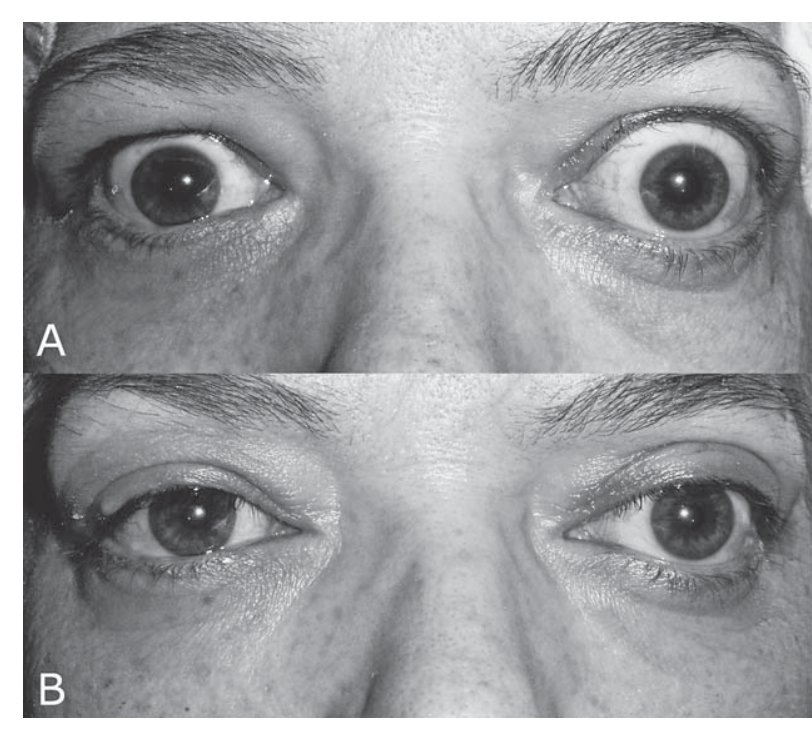

Fig. 2. Case 2 preoperatively $(A)$ and 3 years postoperatively (B).

Table 1. Preoperative and postoperative eyelid measurements

\begin{tabular}{|l|l|l|l|l|l|l|l|}
\hline & \multicolumn{3}{|l|}{ Preoperative eyelid measurements $(\mathrm{mm})$} & \multicolumn{3}{l|}{ Postoperative eyelid measurements $(\mathrm{mm})$} \\
\cline { 2 - 8 } & PA & $\begin{array}{l}\text { MRD } \\
1 / 2\end{array}$ & Skin crease & $\begin{array}{l}\text { DFG } \\
\text { height }\end{array}$ & PA & $\begin{array}{l}\text { MRD } \\
1 / 2\end{array}$ & Skin crease \\
\hline Case 1, RE & 19 & $8 / 11$ & 10 & 12 & 14 & $3 / 11$ & 13 \\
Case 1, LE & 16 & $6 / 10$ & 10 & 10 & 10 & $0 / 10$ & 15 \\
Case 2, RE & 12 & $5 / 7$ & 8 & 6 & 9 & $2 / 7$ & 8 \\
Case 2, LE & 19 & $9 / 10$ & 8 & 12 & 12 & $3 / 10$ & 10 \\
\hline
\end{tabular}

$\mathrm{RE}=$ right eye $\mathrm{LE}=$ left eye; $\mathrm{PA}=$ palpebral aperture; $\mathrm{MRD} 1 / 2=$ margin-to-reflex distance 1 and $2 ; \mathrm{DFG}$ height $=$ dermis-fat graft height required

emia and punctate keratitis were found. Case 1 already had central corneal scarring due to exposure keratopathy on the right eye.

An informed written consent for the surgery was obtained. The patients underwent bilateral upper eyelid retractor recession via anterior approach with dermis-fat graft as a spacer. The surgery was performed in local anesthesia as a unilateral procedure, with the other eye operated one month later. After marking the upper eyelid skin crease at $8 \mathrm{~mm}$, local anesthetic ( $2 \%$ lidocaine with epinephrine 1:100 000, $2 \mathrm{~mL}$ ) was injected subcutaneously. Aponeurosis of the levator muscle was detached from the tarsal plate and dissected all the way to the superior conjunctival fornix cutting the lateral horn of the aponeurosis and freeing its insertions into the orbicular muscle at the skin crease. Whitnall's ligament was not severed. The con- junctiva and Müller's muscle were preserved. Dermisfat graft was harvested from the left suprapubic region. The transverse length of the graft was $15 \mathrm{~mm}$. Its height was defined by the amount of the lid drop needed (Table 1). Two millimeters were added to the temporal edge of the graft for correction of temporal flare. The fat was trimmed down so that the overall thickness of the graft was $10 \mathrm{~mm}$. The graft was oriented so the fat side was facing the conjunctiva. The dermis was anchored to the tarsal plate inferiorly and dissected aponeurosis superiorly with continuous 6-0 absorbable sutures. The skin was sutured with interrupted 6-0 absorbable sutures, three of which incorporated dermis of the graft to restitute the skin crease. No traction was used. Photo documentation was performed preoperatively and at 7 days, one month, six months, and yearly after surgery. Palpebral aperture, 
margin-to-reflex distance 1 and 2 (MRD 1/2), lid curvature, skin crease, dry eye symptoms and complications were noted for both patients.

Table 1 summarizes preoperative and postoperative eyelid measurements. Palpebral aperture reduction, seen as MRD1 improvement, was present bilaterally in both patients. In Case 1, preoperative skin crease was $10 \mathrm{~mm}$ in both eyes. It was elevated to $13 \mathrm{~mm}$ in the right eye and $15 \mathrm{~mm}$ in the left eye. The left eye overcorrection with slight lid curve asymmetry was noted. In Case 2, the right eye skin crease was $8 \mathrm{~mm}$ as intended. However, the left eye skin crease doubled and gone up to $10 \mathrm{~mm}$. Bilateral good lid curve was achieved. There was a slight left eye undercorrection with lateral flare. Eyelid closure and dry eye symptoms improved in both patients. Minor bulking of the lid as a result of the fat gradually resolved without complications in up to three months. On regular check-ups, no recurrence of retraction was noted to date.

\section{Discussion}

Based on thorough search of the literature, this is the first documentation of dermis-fat graft usage as a spacer in the treatment of upper eyelid retraction. When orbital decompression is indicated, lid correction may be executed simultaneously or as a staged procedure after orbital surgery ${ }^{6}$. Although proptosis reduction itself does not resolve lid retraction, it facilitates lid surgery ${ }^{4,6}$. Unfortunately, our patients refused the indicated orbital procedure. Why dermis-fat graft? The authors have positive experience in dermis-fat graft as a secondary orbital implant and as volume augmentation for reconstruction of deep upper eyelid sulcus in an anophthalmic socket ${ }^{10}$. Also, it proved its value as a primary orbital implant and a lower eyelid spacer $^{11,12}$. It is an autologous material readily available, with low rejection rate and no risk of disease transmission $^{9}$. Dermis-fat graft is the only spacer offering both eyelid lengthening and volume enhancement in a single unit. Introduction of an additional volume with fat into the upper eyelid would serve as a lid weight creating no need for traction suture in the early postoperative period. The major concern the authors had was hair growth. Although mechanical debridement with the blade was performed, no such complications had occurred in our previous cases, which gave us a tailwind to persevere ${ }^{10}$. To be on the safe side, the graft was placed with the fat facing the intact conjunctiva. Furthermore, dermis-fat graft starts at the upper tarsal border, thus coming sparsely in apposition with the cornea. Graft orientation was also determined by the fact that the skin crease needs to be restituted by taking a bite of dermis at the intended level. Bilateral surgery was avoided due to prolonged, although minor lid bulkiness caused by added fat, as well as unpredictability of absorption attributed to autologous spacer material ${ }^{10}$. Lower abdomen was chosen as the harvest site because only a rather thin fat layer of the graft was desirable. It ought to be the left side, so that the scar should not be mistaken for the one after appendectomy. The exact location and the suturing technique the author applied ensured minimal scarring ${ }^{10}$. Lateral eyelid lowering is the most difficult part of retraction surgery. If the eyelid is still high after the lateral levator horn has been severed, the lateral end of Whitnall's ligament should be cut ${ }^{2}$. Thus, its fulcrum effect for the levator muscle is lost and levator efficacy diminished ${ }^{2}$. However, the eyelid stability is also threatened. Since the authors added an additional weight, the eyelid support must not be compromised. That is why we spared Whitnall's ligament. However, undercorrection with residual lateral flare in Case 2 made us reconsider the procedure for upcoming cases. There is a problem of the risen skin crease in three of four lids despite prevention measures including anterior approach, cut at the intended level of skin crease and three skin absorbable sutures incorporated into the dermis. In our opinion, lengthening and weakening of Muller's muscle/ levator complex might permit the crease to gradually elevate since the normal skin crease is partially affixed by the tug of the underlying levator muscle.

In conclusion, to the best of our knowledge, this is the first report of dermis-fat graft used as a spacer in upper lid retraction repair. Having positive experience with dermis-fat graft in other eyelid pathologies, the authors gave it a go at four recalcitrant eyelids. Although novel, dermis-fat graft once again proved itself as a possibly successful method for correction of recurrent severe upper eyelid retraction in Graves' orbitopathy. Improvement was achieved with minimal complications, patient symptoms were reduced, and the results achieved have remained stable for almost fouryear follow up to date. However, a larger number of patients are needed to establish the true efficacy and safety of the method. 


\section{References}

1. Ueland HO, Ucherman A, Rødahl E. Levator recession with adjustable sutures for correction of upper eyelid retraction in thyroid eye disease. Acta Ophthalmol. 2014;92:793-7. doi: 10.1111/aos.12404.

2. Collin JRO. A Manual of Systematic Eyelid Surgery. $3^{\text {rd }}$ edn. Elsevier Butterworth Heinemann; 2006. p. 26-7.

3. Small RG. Surgery for upper eyelid retraction, three techniques. Trans Am Ophthalmol Soc. 1995;93:353-69.

4. Kazim M, Gold KG. A review of surgical techniques to correct upper eyelid retraction associated with thyroid eye disease. Curr Opin Ophthalmol. 2011;22(5):391-3. doi: 10.1097/ICU.0b013e3283499433.

5. Watanabe A, Shams PN, Katori N, Kinoshita S, Selva D. Turnover orbital septal flap and levator recession for upper-eyelid retraction secondary to thyroid eye disease. Eye (Lond). 2013;27(10):1174-9. doi: 10.1038/eye.2013.160.

6. Ben Simon GJ, Mansury AM, Schwarcz RM, Lee S, McCann JD, Goldberg RA. Simultaneous orbital decompression and correction of upper eyelid retraction versus staged procedures in thyroid-related orbitopathy. Ophthalmology. 2005;112(5):923-32.
7. Fenton S, Kemp EG. A review of the outcome of upper lid lowering for eyelid retraction and complications of spacers at a single unit over five years. Orbit. 2002;21(4):289-94.

8. McCord C, Nahai FR, Codner MA, Nahai F, Hester TR. Use of porcine acellular dermal matrix (Enduragen) grafts in eyelids: a review of 69 patients and 129 eyelids. Plast Reconstr Surg. 2008;122(4):1206-13. doi: 10.1097/PRS.0b013e3181845888.

9. Smith B, Bosniak S, Nesi F, Lisman R. Dermis-fat orbital implantation: 118 cases. Ophthalmic Surg. 1983;14:941-3.

10. Kuzmanović Elabjer B, Bušić M, Bosnar D, Elabjer E, Miletić D. Our experience with dermofat graft in reconstruction of anophthalmic socket. Orbit. 2010;29(4):209-12. doi: 10.3109/01676830.2010.485716.

11. Korn BS, Kikkawa DO, Cohen SR, Hartstein M, Annunziata CC. Treatment of lower eyelid malposition with dermis fat grafting. Ophthalmology. 2008;115(4):744-51.

12. Nentwich MM, Schebitz-Walter K, Hirneiss C, Hintschich C. Dermis fat grafts as primary and secondary orbital implants. Orbit. 2014;33(1):33-8. doi: $10.3109 / 01676830.2013 .844172$

Sažetak

\section{PRESADAK DERMIS-FAT U KOREKCIJI TEŠKE REKURENTNE RETRAKCIJE GORNJE VJEĐE KOD GRAVESOVE ORBITOPATIJE}

\section{B. Kuzmanović Elabjer, D. Miletić, M. Bušić, A. Bišćan Turdi, D. Bosnar i M. Bjeloš}

Presadak dermis-fat pokazao se kao korisno zamjensko tkivo pri rekonstrukciji vjeđa i orbite, no nema literaturnih dokaza njegove uporabe u korekciji retrakcije gornje vjeđe. Ovo je prvo izvješće koje prikazuje dva slučaja (četiri gornje vjeđe) uporabe presatka dermis-fat kao umetka (spacer) u liječenju teške rekurentne retrakcije gornje vjeđe kod Gravesove orbitopatije. U oba slučaja postignuto je poboljšanje uz minimalne komplikacije, smanjene su subjektivne smetnje bolesnika, a rezultati su ostali stabilni i četiri godine nakon zahvata.

Ključne riječi: Gravesova oftalmopatija - kirurgija; Očni kapci-kirurgija; Rekonstrukcijski kirurški postupci - metode; Koža, transplantacija; Autotransplantat; Presadak dermis fat 